\title{
СПЕЦИФИКА ПОКАЗАТЕЛЕЙ ЛИПИДНОГО ОБМЕНА ПРИ САХАРНОМ ДИАБЕТЕ 2 ТИПА У БОЛЬНЫХ ШИЗОФРЕНИЕЙ
}

\author{
'Ромасенко Л.В., ${ }^{2}$ Третьяков А.Ю., ${ }^{2,3}$ Ермилов О.В.
}

\begin{abstract}
'Федеральное государственное бюджетное учреждение «Национальный медицинский исследовательский центр психиатрии и наркологии имени В.П. Сербского» Министерства здравоохранения Российской Федерации, г. Москва

${ }^{2}$ ФГАОУ ВО «Белгородский государственный национальный исследовательский университет» (НИУ «БелГУ») ${ }^{3}$ ОГБУз Белгородская областная клиническая больница Святителя Иоасафа, г. Белгород
\end{abstract}

ЦЕЛЬ: анализ специфики липидного обмена при сахарном диабете 2 типа (СД2) у больных шизофренией

МАТЕРИАЛЫ И МЕТОДЫ: Сформированы 2 групПЫ, Уравновешенные по основным антропометрическим и демографическим характеристикам: основная - 25 пациентов с СД2 психиатрического стационара (10 мужчин, 15 женщин) и контрольная - психически здоровые пациенты с СД2 (39 человек): 17 мужчин, 22 женщины. Проведена оценка уровня общего холестерина (OХC), фракций липопротеидов высокой плотности (ЛПВП), липопротеидов очень низкой плотности (ЛПОНП), триглицеридов (ТГ), значений коэффициента атерогенности (КА).

PЕЗУЛЬтАТЫ: на фоне практически совпадающих главных антропометрических характеристик, больных шизофренией, в отличие от психически здоровых с СД2, характеризует существенно меньшие уровни ЛПВП и более высокие значения КА. Так, концентрация ЛПВП на 16,4\% ( $=0.029)$ при психозе уступала

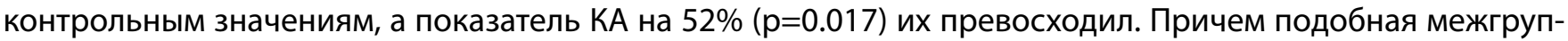
повая разница достигалась результатом показателя у женщин ( $<<0.001, p=0.002)$, тогда как для мужчин подобное правило отсутствовало ( $p=0.604, p=0.675)$. По остальным параметрам липидограммы межгрупповая разница отсутствовала (ОХс, $\mathrm{p}=0.352 ; \mathrm{T \Gamma}, \mathrm{p}=0.662 ;$ лПОНП, $\mathrm{p}=0.166$ ).

Выводы: таким образом, важным свойством психиатрической выборки являлась более выраженная степень дислипидемии, преимущественно у женщин. Данное обстоятельство предполагает включение в диагностическую программу исследования показателей липидограммы у пациентов с шизофренией.

КЛЮЧЕВЫЕ СЛОВА: дислипидемия; сахарный диабет 2 типа; шизофрения. 